\title{
MANAJEMEN PROGRAM PENGELOLAAN SAMPAH DI BENING SAGULING FOUNDATION
}

\author{
Wedi Fitriana ${ }^{1}$, Dinno Mulyono ${ }^{2}$ \\ 1, 2 IKIP Siliwangi \\ dinno@ikipsiliwangi.ac.id
}

\begin{abstract}
ABSTRAK
Program pengelolaan sampah menjadi salah satu permasalahan utama yang tengah berkembang di Jawa Barat, dengan jumlah penduduk mencapai 47 juta jiwa, Jawa Barat selain memiliki potensi sumber daya manusia yang sangat besar, juga memiliki tantangan yang besar juga dalam bidang pengelolaan sampah domestik, industri hingga limbah lainnya. Citarum adalah salah satu sungai terbesar di Indonesia, dan melewati tidak kurang dari 11 Kabupaten/ Kota yang ada di Jawa Barat. Pengelolaan sampah yang belum optimal, membuat Citarum menjadi tempat pembuangan sampah yang sangat besar. Sehingga perlu untuk mengelola dan menjaga agar Citarum tetap lestari. Bening Saguling Foundation adalah salah satu lembaga swadaya masyarakat yang bergerak dalam bidang pendidikan dan ekonomi dalam rangka mengembangkan proses edukasi terhadap masyarakat mengenai pengelolaan sampah yang baik. Oleh karena itu, perlu untuk dilaksanakan program pengabdian kepada masyarakat untuk mendukung program tersebut. Tujuan utama pengabdian ini adalah untuk memberikan dukungan terhadap program Citarum Harum dan mengimplementasikan pendekatanpendekatan yang digunakan pendidikan masyarakat untuk memberikan edukasi kepada masyarakat tentang pengelolaan sampah. Landasan teori yang digunakan adalah tentang pemberdayaan masyarakat sekitar DAS Citarum dan Manajemen Program Pendidikan Masyarakat. Metode pelaksanaan yang dipilih adalah melalui pelatihan dan pembinaan terhadap masyarakat. Untuk hasil yang diperoleh adalah adanya perubahan pandangan masyarakat mengenai pengelolaan sampah di DAS Citarum yang sesuai dengan program pengelolaan sampah yang dilakukan oleh pemerintah. Pembahasan mengemukakan tentang kesesuaian proses pengabdian dengan landasan teori yang digunakan pada program ini. Kesimpulan akhir ditemukan bahwa pengabdian seperti ini perlu untuk dilakukan secara berkesinambungan untuk mengawal proses pelaksanaan program Citarum Harum dan melaksanakan tridharma secara konsisten.
\end{abstract}

Kata Kunci : manajemen, pengelolaan sampah

\begin{abstract}
The waste management program is one of the main problems that is developing in West Java, with a population of 47 million people, West Java besides having enormous human resource potential, also has great challenges in the field of domestic, industrial and waste management. the other. Citarum is one of the largest rivers in Indonesia, and passes no less than 11 regencies / cities in West Java. Waste management is not optimal, making Citarum a very large landfill. So it is necessary to manage and keep Citarum sustainable. Bening Saguling Foundation is one of the non-governmental organizations engaged in education and economics in order to develop an education process for the community regarding good waste management. Therefore, it is necessary to implement a community service program to support the program. The main purpose of this service is to provide support to the Citarum Harum program and implement approaches used by community education to educate the public about waste management. The theoretical foundation used is about community empowerment around the Citarum River Basin and Community Education Program Management. The method of implementation chosen was through training and coaching for the community. For the results obtained is a change in community views about waste management in the Citarum watershed in accordance with the waste management program carried out by the government. The discussion suggests the appropriateness of the service process with the theoretical foundation used in this program.
\end{abstract}


The final conclusion was found that this kind of service needs to be carried out on an ongoing basis to oversee the process of implementing the Citarum Harum program and to implement tridharma consistently.

Keywords: management, waste management

\section{A. PENDAHULUAN}

Satuan pendidikan masyarakat sebagaimana satuan pendidikan lainnya memiliki kebutuhan untuk mendapatkan pengelolaan yang memadai dan dapat dilaksanakan secara konsisten sehingga mampu untuk memberikan pelayanan yang memadai bagi warga belajar dan masyarakat secara umum. Dalam beberapa kesempatan satuan pendidikan masyarakat juga menjadi pusat pertumbuhan kualitas kehidupan masyarakat melalui berbagai pelatihan dan pendampingan bagi masyarakat yang ada di sekitarnya.

Dalam berbagai kesempatan program yang dilaksanakan pada satuan pendidikan masyarakat mendampingkan program pendidikan sekaligus dengan program pengembangan ekonomi yang berkaitan dengan peningkatan kemandirian masyarakat baik secara ekonomi, politik, sosial dan budaya. Oleh karena itu, membutuhkan pengelolaan yang komprehensif dan berhubungan dengan potensi lokal yang dimiliki oleh masyarakat.

Kekuatan budaya dan karakter kehidupan masyarakat menjadi salah satu penguatan utama dalam pengelolaan satuan pendidikan masyarakat, sehingga dengan berbagai program yang ada dapat mengembangkan karakter masyarakat terutama dalam meningkatkan produktivitas masyarakat sehingga membangun kekuatan mandiri yang saling menguatkan dan mendampingi berbagai sisi masyarakat secara menyeluruh dan berkesinambungan.

Kindevatter (1979: 78) memandang pendidikan nonformal (pendidikan masyarakat) sebagai metode pemberdayaan yang berkaitan dengan penguatan masyarakat, terutama budaya produktif seperti gotong royong dan kesadaran kolektif menjadi sebuah kekuatan yang saling menguatkan satu sama lain untuk membangun sistem pendidikan yang menyeluruh. Pendidikan tidak lagi dipandang sebagai investasi jarak jauh atau jangka panjang, melainkan sebagai investasi dalam jangka pendek dan menengah yang secara langsung diaplikasikan dalam kehidupan masyarakat secara berkesinambungan.

Tuuan utama dalam pengelolaan sampah di DAS Citarum adalah untuk menjaga dan melestarikan Sungai Citarum sebagai salah satu sumber kehidupan masyarakat di 
sekitar DAS Citarum. Dengan memberikan dan mengembangkan berbagai pendekatan pendidikan masyarakat yang ada, diharapkan tumbuh kesadaran masyarakat dan dipelihara sebagai salah satu upaya untuk melestarikan sungai Citarum. Citarum yang merupakan salah satu sungai terbesari di Indonesia menjadi salah satu potensi sekaligus tantangan. Pengelolaan DAS Citarum tidak hanya membutuhkan kegiatan yang berkaitan dengan manajemen semata, tapi perlu penguatan dalam konteks pemberdayaan masyarakat.

Pembangunan dan pemberdayaan masyarakat adalah hal yang sangat sering dibicarakan untuk kemajuan dan perubahan bangsa saat ini kedepan, terutama dalam memperhatikan proses perkembangan yang ada di Indonesia saat ini, konsep pemberdayaan masyarakat mencakup pengertian pembangunan masyarakat (community development) dan pembangunan yang bertumpu pada masyarakat (community based development).

Dalam hal ini, makna pemberdayaan dan pembangunan masyarakat perlu untuk mendapatkan kajian yang lebih lengkap, keberdayaan dalam konteks masyarakat adalah kemampuan individu yang bersenyawa dalam masyarakat dan membangun keberdayaan masyarakat yang bersangkutan. Suatu masyarakat yang sebagian besar meliki kesehatan fisik dan mental, serta didik dan kuat inovatif, tentunya memiliki keberdayaan yang tinggi, sedangkan pembangunan masyarakat adalah suatu hal yang perlu di kelola untuk kemampuan masyarakat itu sendiri.

Dalam konteks pemberdayaan masyarakat di DAS Citarum, maka sebanyak mungkin perlu untuk dikembangkan mengenai proses pemberdayaan yang melibatkan peran serta masyarakat (partisipatif) sehingga memberikan kesempatan kepada masyarakat untuk dapat memberikan kontribusi sesuai dengan perannya di tengah masyarakat, tidak hanya menjadi sasaran yang pasif. Karena program pengelolaan sampah melibatkan rumah tangga, tidak hanya industri. Terutama dengan semakin berkembangnya dan adanya Satuan Tugas Citarum Harum yang langsung ditugaskan oleh Presiden Republik Indonesia. Mengingat Citarum melewati tidak kurang dari 11 Kabupaten dan Kota di Jawa Barat, yang memiliki kepadatan penduduk hingga 47 juta jiwa.

Pembangunan berbasis sumber daya lokal dan pemberdayaan dalam prakteknya menempatkan titik pangkal pembangunan pada "level bawah" bukan pada "level atas", kemudian pada penerapannya bervariasi sesuai potensi dan karakteristik daerah 
masing-masing, Pendekatan pemberdayaan yang berpusat pada manusia (people centered development) ini kemudian melandasi wawasan pengelolaan sumberdaya lokal (community-based resources management), yang merupakan mekanisme perencanaan people centered development yang menekankan pada teknologi pembelajaran sosial (social learning) dan strategi perumusan proyek. Adapun tujuan yang ingin dicapai adalah untuk meningkatkan ke mampuan masyarakat dalam mengaktualisasikan dirinya (empowerment).

Prinsip pemberdayaan ditekankan akan adanya pola kesinambungan antara program yang dijalankan dengan hasil yang didapat. Nantinya akan terlihat perubahan dalam wujud indikator-indikator yang bisa dinilai dan dievaluasi untuk pengembangan pemberdayaan selanjutnya. Pola pemetaan dalam kebutuhan masyarakat diperlukan sebagai acuan untuk tindak apa yang bisa dilakukan dalam proses pemberdayaan ini. Pendekatan utama dalam konsep pemberdayaan adalah bahwa masyarakat tidak dijadikan objek dari berbagai proyek pembangunan, tetapi merupakan subjek dari upaya pembangunannya sendiri.

Bila diperlukan program pemberdayaan dan pengelolaan sampah yang dilaksanakan di Bening Saguling Foundation harus memperkuat pendekatan berbasis keluarga, sehingga mulai dari lingkungan keluarga masyarakat dapat mengembangkan berbagai pendekatan yang lebih erat dan dekat dengan kehidupan masyaarakat, hal ini sesuai dengan pendapat dari A. S. Akhyadi dan Mulyono (2018) yang menyebutkan bahwa proses pendidikan yang paling pertama dalam membangun karakter masyarakat adalah lingkungan keluarga. Termasuk dalam mengedepankan pendekatan pengelolaan yang lebih humanistik dan produktif.

Pengelolaan program pada lembaga pendidikan masyarakat juga membutuhkan adanya pendekatan khusus yang lebih komprehensif untuk mendukung proses pemberdayaan itu sendiri. Berdasarkan konsep pengelolaan pendidikan masyarakat yang dikemukakan oleh D. Sudjana (2001) dikemukakan bahwa Pengelolaan dalam program pendidikan masyarakat sangatlah penting, dengan adanya pengelolaan maka tujuan yang telah ditetapkan dari program pendidikan masyarakat dapat berjalan dengan efektif dan efisien yaitu dimana program yang dijalankan tersebut tepat sasaran dan dapat memberi manfaat bagi masyarakat atau warga belajar. Oleh karena itu dibutuhkan rangkaian kegiatan sebagai upaya dalam pengelolaan program pendidikan masyarakat yaitu dari perencanaan, pengorganisasian, pengarahan, pengawasan, dan 
pengembangan.Berdasarkan pada berbagai uraian diatas, maka perlu untuk dirumuskan sebuah program pengabdian yang berfokus pada program pengelolaan sampah yang dilaksanakan di Bening Saguling Foundation, Desa Cihampelas, Kecamatan Cihampelas Kabupaten Bandung Barat. Oleh karena itu, program ini berupaya untuk mengedepankan proses pendekatan pengelolaan yang dianggap perlu untuk dapat membangun kesadaran masyarakat tentang pengelolaan sampah.

\section{B. LANDASAN TEORI}

Pengelolaan sampah merupakan proses yang mengedepankan pada pola pendekatan 3R yaitu reduce, reuse dan recycle. Sampah saat ini menjadi persoalan pokok di Indonesia, dengan bertambahnya jumlah penduduk, urbanisasi, perubahan pola konsumsi, gaya hidup masyarakat, pertumbuhan ekonomi, dan kemajuan teknologi masyarakat sehingga meningkatkan jumlah timbulan sampah, jenis, dan keberagaman karakteristik sampah (Trihadiningrum, 2010 dalam, 2018; 238-246). Pengolahan sampah yang dilakukan pada tingkat rumah tangga dengan menggunakan metode pengolahan sampah $3 \mathrm{R}$, maka dapat berdampak positif pada kesehatan dan kesejahteraan masyarakat (D. Ediana, F. Fatma dan Yuniliza, 2018; 238-246). Mengurangi penyakit yang berhubungan dengan sampah, dan sampah-sampah yang dapat didaur ulang dan kompos dapat meningkatkan tingkat ekonomi masyarakat.

Konsep reduce, reuse, recycle sendiri merupakan cara yang paling efektif saat ini dalam menanggulangi masalah sampah karena sistem ini menyentuh akar permasalahan dari sampah tersebut yaitu dengan mengurangi sampah. "Idealnya dengan pengurangan sampah ini sudah dapat dimulai sejak dari awal sumbernya. Hal ini berhubungan langsung dengan peran serta masyarakat sebagai penghasil sampah itu sendiri" (Sucipto, 2012:15-16; Subekti, 2017: 550-560). Dengan menggunakan proses pendekatan 3R diharapkan masyarakat akan tergerak dan mulai mengembangkan manajemen pengelolaan sampah yang lebih baik. Pendekatan pendidikan masyarakat sendiri dikembangkan untuk membangun kesadaran secara menyeluruh melalui internalisasi pemahaman yang dilaksanakan secara konsisten. Penggunaan pendekatan pendidikan masyarakat akan memberikan penguatan terhadap kapasitas kehidupan masyarakat yang lebih baik (Saepudin dan Mulyono, 2019: 65-73). 


\section{METODE PELAKSANAAN}

Metode pelaksanaan pengabdian kepada masyarakat dilakukan dengan menggunakan pendekatan pelatihan dan pendampingan. Pelatihan Pelatihan juga merupakan upaya pembelajaran yang diselenggarakan oleh organisasi baik pemerintah, maupun lembaga swadaya masyarakat ataupun perusahaan dengan tujuan untuk memenuhi kebutuhan organisasi dan mencapai tujuan organisasi. Pengertian ini didasarkan pada definisi yang dikemukakan oleh Sudjana (2007) bahwa : "Training is a process used by organization to meet their goals. It is called into operation when a discrepancy is perceived between the current situation and a preferred state of affairs". Pelatihan adalah upaya pembelajaran yang diselenggarakan oleh organisasi (instansi pemerintah, lembaga swadaya masyarakat, perusahaan) untuk memenuhi kebutuhan atau untuk mencapai tujuan organisasi sehingga pelatihan dapat diartikan sebagai kegiatan edukatif untuk membawa keadaan perilaku peserta pelatihan saat ini kepada perilaku yang lebih baik sebagaimana yang diinginkan oleh organisasi. Dengan demikian program pelatihan juga menjadi salah satu penguatan dalam upaya peningkatan pemahaman masyarakat tentang DAS Citarum dan berbagai pengelolaan untuk mendukung pelestarian Citarum. Program pelatihan yang dilaksanakan bertujuan untuk membangun kesadaran masyarakat tentang proses pengelolaan sampah yang ada di DAS Citarum. Terutama bagi masyarakat yang menjadi sasaran atau anggota dari Bening Saguling Foundation, di Desa Cihampelas, Kecamatan Cihampelas, Kabupaten Bandung Barat.

Sedangkan pendampingan adalah Pendampingan adalah suatu proses pemberian kemudahan (fasilitas) yang diberikan pendamping kepada klien dalam mengidentifikasi kebutuhan dan memecahkan masalah serta mendorong tumbuhnya inisiatif dalam proses pengambilan keputusan, sehingga kemandirian klien secara berkelanjutan dapat diwujudkan (Direktorat Bantuan Sosial, 2007: 4). Pendampingan dalam kegiatan pengabdian ini lebih diarahkan dalam rangka menumbuhkan kemandirian masyarakat setelah mengikuti pelatihan yang dilaksanakan sebelumnya, sehingga pada saat tim pengabdian kembali ke perguruan tinggi, masyarakat tetap dapat melaksanakan program secara mandiri. 


\section{Hasil dan Pembahasan}

\section{Hasil}

Hasil pengabdian yang diperoleh adalah adanya hasil dari program pelatihan tentang pengelolaan sampah yang dilakukan oleh tim pengabdian kepada masyarakat IKIP Siliwangi dan pengelola Bening Saguling Foundation. Terutama dalam hal pengelolaan sampah dan pemanfaatan yang berkaitan dengan lingkungan rumah tangga dan masyarakat di sekitar. Peserta yang mengikuti pelatihan sebanyak 15 orang dari 15 kepala keluarga yang berbeda, yang juga menjadi anggota masyarakat binaan dari Bening Saguling Foundation. Acara pelatihan difokuskan di aula Bening Saguling Foundation di Desa Cihampelas, Kecamatan Cihampelas, Kabupaten Bandung Barat.

Dengan berbagai pendekatan yang ada diharapkan agar proses pelatihan mampu memberikan nilai tambah dalam proses peningkatan kualitas kehidupan di tengah masyarakat. Pelatihan memberikan pemahaman tentang pemilahan sampah, pengelolaan sampah dan pengolahan sampah. Untuk pemilahan sampah masyarakat diberikan pengetahuan tentang sampah organik dan anorganik, sedangkan untuk pengelolaan sampah, masyarakat diberikan teknik dan pengetahuan tentang penanganan sampah organik dan anorganik. Untuk sampah organik yang dapat digunakan menjadi kompos, maka masyarakat diberikan pelatihan pemanfaatan komposter dan biopori. Untuk sampah anorganik, masyarakat diberikan pelatihan tentang pemanfaatan botol bekas menjadi ecobrick, pengolahan bijih plastik hingga pemanfaatan bungkus plastik untuk dijadikan beragam kerajinan yang bernilai ekonomis.

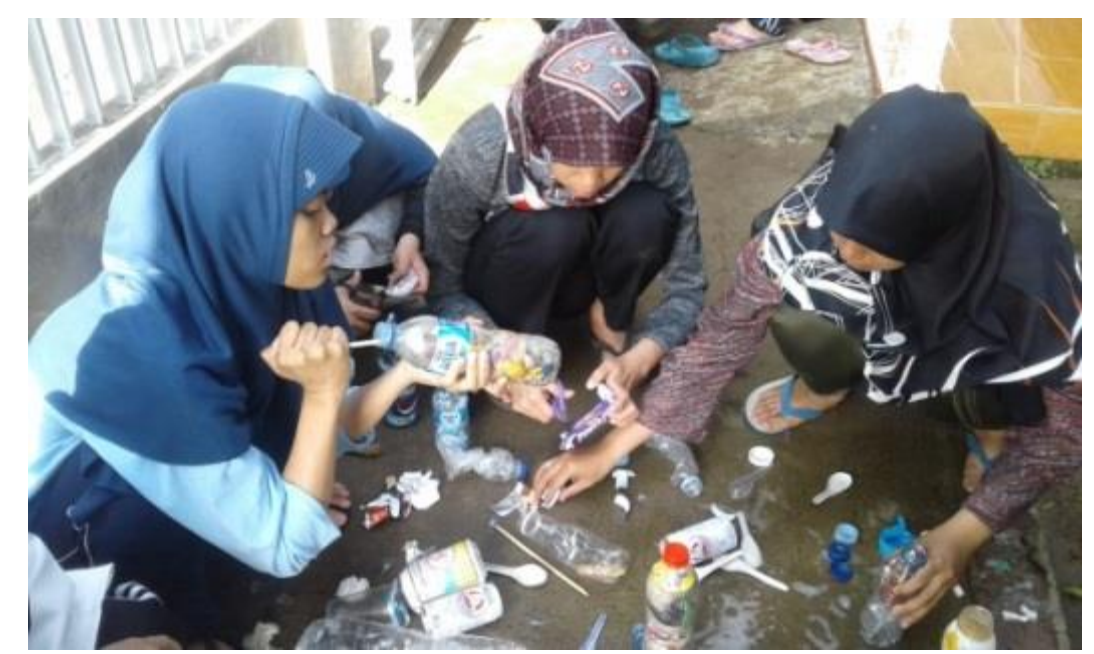

Gambar 1. Pemilahan Botol Bekas untuk Ecobrick 


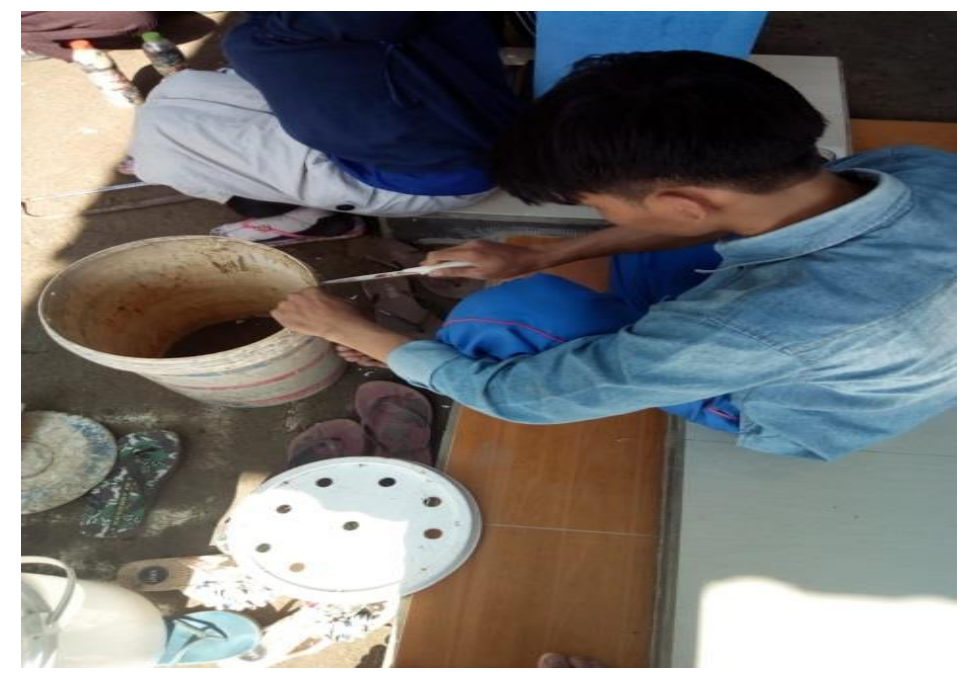

Gambar 2. Penggunaan Kaleng Cat Bekas menjadi Bio pori Jumbo

Untuk pendampingan, program pengabdian ini memberikan kesempatan kepada para tutor di Bening Saguling Foundation yang disertai dari tim pengabdian kepada masyarakat IKIP Siliwangi, untuk melihat secara langsung aplikasi hasil pelatihan yang telah dilaksanakan sebelumnya, sehingga dapat terpantau proses pemanfaatan hasil pelatihan yang dilaksanakan di Bening Saguling Foundation. Dari hasil pendampingan, terlihat bahwa beberapa keluarga telah berhasil memahami dan melaksanakan pemanfaatan dan pengelolaan sampah. Sedangkan ada beberapa keluarga yang mengalami kesulitan karena masalah sempitnya lahan yang ada di sekitar rumah.

\section{Pembahasan}

Mengenai program pelatihan yang telah dilaksanakan di Bening Saguling Foundation, telah dijelaskan mengenai proses pemilahan, penggunaan ulang dan pendaurulangan sampah bagi masyarakat. Masyarakat ternyata memberikan respon yang cukup baik dibandingkan dengan proses pada saat sebelum dilaksanakan terutama setelah memahami proses pengolahan sampah yang dilakukan di Bening Saguling Foundation. Dengan adanya hal tersebut, masyarakat terdorong untuk dapat melaksanakan program pengolahan sampah di keluarganya masing-masing. Pelatihan dengan menggunakan pendekatan pendidikan masyarakat memberikan implikasi yang cukup baik untuk mendukung peningkatan partisipasi masyarakat. Hal ini senada dengan pendapat dari Kindevatter (1979: 78) yang memandang pendidikan nonformal (pendidikan masyarakat) sebagai metode pemberdayaan yang berkaitan dengan penguatan masyarakat, terutama budaya produktif seperti gotong royong dan kesadaran kolektif menjadi sebuah kekuatan yang saling menguatkan satu sama lain untuk membangun 
sistem pendidikan yang menyeluruh. Sehingga pendidikan tidak lagi dipandang sebagai investasi jangka panjang, melainkan sebagai investasi dalam jangka pendek dan menengah yang secara langsung diaplikasikan dalam kehidupan masyarakat secara berkesinambungan.

Pendampingan yang dilakukan menunjukkan hampir 70\% peserta dari 15 anggota yang mengikuti pelatihan telah menunjukkan adanya perubahan yang cukup baik dalam pengelolaan sampah. Pendampingan ternyata memberikan penguatan terhadap kapasitas kehidupan masyarakat secara baik. Pendampingan dapat dipahami sebagai kegiatan pemberdayaan masyarakat dengan menempatkan tenaga pendamping sebagai fasilitator, komunikator, motivator dan dinamisator. Pada dasarnya, pendampingan merupakan upaya untuk menyertakan masyarakat dalam mengembangkan berbagai potensi sehingga mampu mencapai kualitas kehidupan yang lebih baik. Selain itu diarahkan untuk memfasilitasi proses pengambilan keputusan yang terkait dengan kebutuhan masyarakat, membangun kemampuan dalam meningkatkan pendapatan, melaksanakan usaha yang berskala bisnis serta mengembangkan perencanaan dan pelaksanaan kegiatan partisipatif. Pendampingan pada intinya didasari oleh prinsip pemihakan kepada kelompok-kelompok masyarakat yang marginal, tertindas dan 14 dibawah untuk menjadikan mereka mempunyai posisi tawar sehingga mampu memecahkan masalah dan mengubah posisinya. Pendampingan dengan konsep mencakup upaya perbaikan kualitas hidup rakyat yang diukur dari peningkatan kesejahteraan ekonomi, partisipasi. Menurut Juni Thamrin dan Suhendar (1996: 89), yaitu banyak cara melakukan pendampingan dan salah satunya melalui kunjungan ke lapangan, tujuan kunjungan kelapangan ini adalah membina hubungan kedekatan dengan masyarakat, kedekatan dapat menimbulkan kepercayaan antara 15 pendamping dengan yang didampingi. Sehingga mampu menunjukkan adanya berbagai perubahan yang berkaitan dengan pengelolaan sampah di tingkat keluarga dan masyarakat, di Desa Cihampelas, Kecamatan Cihampelas, Kabupaten Bandung Barat.

\section{E. KESIMPULAN}

Berdasarkan kegiatan yang dilakukan untuk program pengabdian kepada masyarakat diperoleh bahwa masyarakat menunjukkan proses yang cukup baik untuk memahami program pengelolaan sampah di tingkat rumah tangga. Hal ini diindikasikan dengan bersedianya anggota masyarakat yang menjadi peserta dalam program 
pengabdian ini untuk melaksanakan program pemilahan sampah dan menggunakan biopori untuk pemanfaatan sampah, bahkan pada beberapa kesempatan melaksanakan pengembangan komposter yang dibangun di lingkungan sekitar rumah. Pemanfaatan limbah plastik juga digunakan dengan dimanfaatkan menjadi seni kerajinan yang bermanfaat seperti kantong belanja (goody bag) dan sebagainya. Walaupun dalam skala yang kecil tapi diharapkan dapat membangun kesadaran masyarakat secara keseluruhan di masa yang akan datang.

\section{F. UCAPAN TERIMA KASIH}

Ucapan terima kasih disampaikan kepada IKIP Siliwangi, terutama pimpinan dan LPPM IKIP Siliwangi yang telah memberikan dukungan dan bantuan dalam pelaksanaan program pengabdian ini melalui Hibah Pengabdian Internal IKIP Siliwangi tahun pendanaan 2019.

\section{G. DAFTAR PUSTAKA}

Akhyadi, A. S., \& Mulyono, D. (2018). Program Parenting dalam Meningkatkan Kualitas Pendidikan Keluarga. Abdimas Siliwangi: Jurnal Pengabdian Kepada Masyarakat, 1(1), 1-8.

Ediana, D., Fatma, F., \& Yuniliza. (2018). ANALISIS PENGOLAHAN SAMPAH REDUCE, REUSE, RECYCLE (3R) PADA MASYARAKAT DI KOTA PAYAKUMBUH. Jurnal Endurance 3(2) Juni 2018, 238-246.

Kindevatter, S. (1979). Nonformal Education As An Empowering Process. New York: Printers in UNited States of America.

Saepudin, A., \& Mulyono, D. (2019). Community Education In Community Development. EMPOWERMENT: Jurnal Ilmiah Program Studi Pendidikan Luar Sekolah, 8(1), 6573.

Sosial, D. B. (2007). Jaminan Kesejehteraan. Sosial Melalui Inisiatif Lokal. Jakarta: Dirjen Bantuan dan Jaminan Sosial, Kementerian Sosial Republik Indonesia.

Subekti, F. (2017). IMPLEMENTASI REDUCE, REUSE, RECYCLE (3R) DALAM MENUMBUHKAN KEPEDULIAN ANAK TERHADAP LINGKUNGAN DI PAUD GAJAH WONG, BALEREJO, MUJAMUJU, UMBULHARJO, DIY. Jurnal Pendidikan Luar Sekolah, 6(6) , 550-560. 
Sucipto, C. (2012). Teknologi Pengelolaan Daur Ulang Sampah. Yogyakarta: Goysen Publishing.

Sudjana, D. (2001). Pendidikan Luar Sekolah, Falsafah, Wawasan, Sejarah, Teori Pendukung. Bandung: Falah Production.

Sudjana, D. (2007). Manajemen dan Sistem Pelatihan. Bandung : Falah Production.

Thamrin, J., \& Suhendar, E. (1996). Industrialisasi Kehutanan dan Dampaknya Terhadap Masyarakat Adat. Bandung: Akatiga. 